\title{
Inaccuracy within Online Journalism in Indonesia
}

\author{
Fikry Zahria Emeraldien ${ }^{1}$, Rahma Sugihartati ${ }^{2}$, Titik Puji Rahayu ${ }^{3}$ \\ ${ }^{1}$ ORCID iD: 0000-0003-1092-6045, Universitas Airlangga, J1. Airlangga No. 4-6, \\ Surabaya, East Java 60115, Indonesia \\ ${ }^{2}$ ORCID iD: 0000-0003-3137-8607, Universitas Airlangga, Jl. Airlangga No. 4-6, \\ Surabaya, East Java 60115, Indonesia \\ ${ }^{3}$ ORCID iD: 0000-0002-1536-235X, Universitas Airlangga, J1. Airlangga No. 4-6, \\ Surabaya, East Java 60115, Indonesia \\ *Corresponding author, e-mail: fikry.zahria.emeraldien-2019@fisip.unair.ac.id
}

\begin{abstract}
Many scholars have conducted studies on the accuracy of the news media, such as newspaper, television, and magazine, but not online media. In fact, online media is a significant news media in the moment, especially in Indonesia. Online press companies are even the largest press companies in Indonesia compared to newspapers, radio, and television. Therefore, this study is conducted to measure the inaccuracies that occur in news in online news media. Researchers examined 63 online journalistic media that have been administratively and factually verified by the 'Dewan Pers' (Press Council). It uses a content analysis method by coding the headlines in Indonesian online journalistic media. This study finds online mass media categories based on the theme segmentation, namely: 1) general, 2) economics, technology, and business, 3) sports, 4) politics, law, and crime, 5) lifestyle and entertainment, and 6) regional. The results of this study indicate that the inaccuracy of news in Indonesian online media is high. Media with economics, technology, and business most often make grammatical errors. This study also finds that speed does not only has an impact on grammatical inaccuracies, but also on unbalanced news reporting, where the imbalance in Indonesian online media news itself is very high.
\end{abstract}

Keywords: News Inaccuracy, Dewan Pers, Indonesian Online Media, Grammatical Inaccuracies, Unbalanced News Reporting.

\section{Introduction}

Accuracy was an interesting theme that has been a concern for mass media or journalistic researchers several decades ago. Three legendary studies on accuracy in the mass media are "Newspaper Accuracy in Tucson" (Berry, 1967), "A Study of Accuracy in Local News Stories of Three Dailies" (Marshall, 1972), and "Accuracy in Local TV News" (Michael W. Singlatery; Richard Lipsky, 1977). The three of them examined the accuracy of news in traditional mass media, namely newspapers and television.

Different from all of studies aforementioned, this research examines the accuracy of news in online journalistic media. This is due to the large number of news media whose accuracy has been studied, but not online media. In other words, researching the accuracy of news stories on online journalistic media is itself a novelty. In addition, we also carried out other novelties, namely: 1) categorizing various types of online media based on their theme segmentation and 2) revealing whether the news reports in Indonesian online media are more likely balanced or not, where balance itself is the main thing in news writing because journalists must do cover both sides, not one side only.

We chose online media as the object of research also because this platform has the characteristics of prioritizing speed (Brautović et al., 2020), so the accuracy of the news is often questioned. This study is significant to be carried out, because online media is a medium that is very widely used, especially in Indonesia. From the total of 1438 press 
companies in Indonesia, 661 is online media. This research will also enrich the discussion about journalism in the digital era. This will complement the journalistic research themes that are mainly about media agendas (Joye, 2010), social media (Karyotakis et al., 2019), globalization (Cunningham \& Craig, 2016), media convergence (Alzamora \& Tárcia, 2012), and big data (Coddington, 2015).

Journalism is now leading to online. This occurs in various countries, both in countries that already have converged journalistic media (Jacobson, 2010) and in Indonesia itself. In this condition, there are many opinions or viewpoints related to the sustainability of the mass media. One of the papers say that the printed media is now dead due to the digital age and the covid-19 pandemic (Supadiyanto, 2020).

According to Berry, the accuracy of media and public trust need to be continuously researched and checked through a news report. He suggested that examinations shouldn't just be limited to newspapers. The accuracy of news magazines, business press, radio and television also needs to be studied (Berry, 1967), especially online media which is the newest media in news coverage. Therefore, this research is written in order to meet the demands of the novelty.

Accuracy is interpreted as very important in journalism. The things that are often violated or the mistakes that are most often found in print media are omissions, misquotations, and typos. 'Objective' errors such as name, age, and the like occur more frequently in spot news than anticipated (Berry, 1967). Meanwhile, in the television media, inaccuracies were also found. In their study, Singlatery and Lipsky found that the accuracy of newspaper news is higher than the accuracy of television news. Print media are considered more reliable than magazine news and radio news (Michael W. Singlatery; Richard Lipsky, 1977).

Currently, what has not been answered is how accurate is the online journalistic media in Indonesia; therefore, this article is significant. Instead of using the word accuracy, we are more interested in writing down 'inaccuracy.' This is because online news media in Indonesia have been verified by the 'Dewan Pers' (Press Council). By the end of 2020, from the 661 existing online media in Indonesia, 199 of them has passed verification and is declared as factual by 'Dewan Pers.'

However, factual are not necessarily free from inaccuracies. In 2015, for example, CNN Indonesia published inaccurate news, even though it was and still a press media that had been administratively and factually verified by 'Dewan Pers.' They wrote inaccurate title about former Indonesian president Megawati's thought towards KPK (Corruption Eradication Commission), at the moment. CNN Indonesia formerly wrote "Megawati: Bubarkan KPK" (Megawati: Disband KPK) then revised it becomes "Megawati: Bubarkan KPK jika Tak Ada Korupsi" (Megawati: Disband KPK if there is not Corruption) (Fauzi, 2015).

The corrections and apologies from CNN Indonesia have been written at the bottom of the story. This is a good thing to do in online media because we can find out the digital footprint of a news report that was not accurate from this way. However, we cannot guarantee that all online media outlets do the same. For this reason, it is important for us to regularly check the accuracy of the news so that the quality of the mass media in Indonesia can be maintained, at least that is what this research is trying to do. By calculating the inaccuracies of news in the media that have been declared factual hopefully can serve as a reminder or help the mass media to maintain their credibility.

Along with the credibility of the news, accuracy is believed to have decreased a lot in the past two decades. However, interestingly, the majority of respondents considered 
media coverage of anthrax to be accurate (Fahmy \& Johnson, 2007). It seems that gender and geographic area relatively can be used as references in predicting media accuracy. Compared to men, women perceive media coverage to be more accurate and tend to have more fear and anxiety after consuming a report about terrorism (Fahmy \& Johnson, 2007).

Different from the research above, this study does not take geographic areas as a determinant of accuracy in news. This is because of our research object--that is news in online media--where there is no area limit in accessing it. Gender itself is also not an indicator in examining news inaccuracies in this study, because this study does not examine the perceptions of readers, but news texts in online journalistic media. This study will also examine how online media in Indonesia enforce ethics.

Media ethics is closely related to accuracy. Media with a lot of inaccuracies in the news are considered to have ethical issues. There is a finding that most journalists view plagiarism, the use of anonymous sources, gossip, and hate speech as the most serious unethical practices associated with new media or the internet (Chari, 2013). There is a view that journalism practitioners who rely too much on new media technology to gather news in the long term can negatively impact the creativity and strength of traditional journalism.

While the journalistic code of ethics in other countries--such as Nigeria, United kingdom, United States of America, India and Russia--is based on nations' politics and cultures (Akoje \& Rahim, 2014), journalistic code of ethics in Indonesia prioritizes independence, balance, and accuracy. As in the first clause, Indonesian journalists are independent, producing news that is accurate, balanced and not with bad intentions. Inaccuracies can arise whether it is due to personal deliberation or coincidence, as what was done by $\mathrm{CNN}$ Indonesia.

The main cause of journalistic errors and their spread is in journalist routines, namely inadequate journalistic practices related to fact checking and correction (Brautović et al., 2020). They found that the media ignored accuracy as an ethical standard in the journalism profession for the sake of publication speed. After reporting news by mistake, many media continue to publish stories that are inaccurate and do not check the correct facts (Brautović et al., 2020). Therefore, inaccuracies in the mass media persist. In this case, it is not the speed of online media or the lack of time that is to blame, but rather flawed routines that leave accuracy as a principle of journalism (Pesquisa, 2017). We agree with the results of this study, even though the actual speed in online media cannot be excluded as the cause of the high accuracy in online media compared to traditional media.

Accuracy is something that can be compromised, it is seen as a professional norm as well as a compromise norm (Shapiro et al., 2013). Compromise is only understood rather than articulated. If there are small facts that are easy to check, they need to be checked. However, if there is a statement that is bigger but 'gray', then the statement is not given much attention; unless it is defamation.

However, verification of news report data is still deemed mandatory in order to maintain news accuracy, especially in the era of 'post truth' (Duffy \& Tan Rui Si, 2018) as it is today; where digital disruption has challenged the norm or in the newsroom. People must be disciplined in conducting verification in journalism. The high compliance with discipline in verification makes a journalist identifiable as a professional group. In conclusion, the validity of news reports needs to be fulfilled (Potter \& Thai, 2019).

If the verification process is ignored, it is not impossible that an online journalistic media will channel fake news or hoaxes (Adhiarso et al., 2018). According to their 
findings, news construction can have a positive effect on hoax reporting in online media. This means that online news has an effect on the spread of hoax news and if more and more internet users respond to hoax news, the wider the circulation of hoax news will be. They concluded that news construction and internet user responses had a positive and significant effect on hoax news in online media. The hope is that online media will certainly not be the distributor of hoaxes. Online media will be useful if it can report factual events or can even be a medium of learning or media for social change (Ma et al., 2018).

Keeping news from hoaxes is also a priority for journalists in online media who focus on entertainment news. This was found in research on the opinion of Buzzfeed journalists (Tandoc \& Foo, 2018). Buzzfeed is an American news company that focuses on entertainment on the Internet media. Much of Buzzfeed's viral content has caught the attention of audiences and researchers in the journalism field. Although based on the distribution of online media, Buzzfeed journalists are still trying to carry on the values or norms that exist in traditional media. One of the norms is accuracy. A Buzzfeed journalist said it was their job to publish honest stories that tell people about the world they experience every day (Tandoc \& Foo, 2018). This indicates that even if a media focuses on entertainment, accuracy is still upheld as a journalistic norm that needs to be maintained.

Based on the background aforementioned, we are interested in researching the accuracy of news in Indonesian online media. This research focuses on what inaccuracies appear in Indonesian online media. This is because, as previously stated, even though the online journalistic media has been verified by the Press Council, inaccuracies may arises. There needs to be a study that examines the inaccuracy of news in online media as a form of concern for the credibility of the news media in Indonesia as a whole. This research, arguably continues what has been done in 'Between clarity and novelty implementation in Indonesia online media according to the principle of journalist' (Rizkiansyah et al., 2020). Even though the methods we use are very different--they conduct interviews with journalists while authors survey the content of the news--our spirit is the same, namely to find out how to implement journalistic principles in online media.

\section{Methods}

This research uses a quantitative method by conducting a survey of the headlines in Indonesian journalistic online media. The approach of content analysis is used to collect and code the data. Universe or population of this study is 63 Indonesian online media that have been administratively and factually verified by the Press Council. These media consist of: 23 media with general discussions; 3 economics, technology, and business media; 1 sports media; 8 politics, law, and crime media; 5 lifestyle and entertainment media; and 23 regional media. Units of analysis of this study are every headline of Indonesian online media that have been determined as sample.

The prior instrument of this research is the coding sheet by using Microsoft Excell. The categories themself are developed by utilizing major parts of Maier's classification of inaccuracies or errors (Maier, 2005) and adjust it to the context in Indonesia. From this adjustment, the categorizations are: 1) gramatical errors (or 'objective errors' in Maier's), 2 ) subjective errors that consist of inaccurate title and imbalance, and 3) source. To ensure the validity of the proposed categorization, we employ two people to code them in the pilot study. These coders have a background that suits the needs of this study, namely: 1) having adequate knowledge about news in online media and 2) understanding journalistic 
ethics and Indonesian language. Work results the two coders are calculated using Cohen's Kappa intercoder reliability consistency test.

\section{Results}

This section shows the research results on the 63 online journalistic media that have been administratively and factually verified by the Press Council. These media have various news segments, ranging from: general; economics, technology, and business; sports; politics, and crime; lifestyle and entertainment; and regional. These media are: Table 1. Online Media Name

\begin{tabular}{|c|c|c|c|}
\hline No & Online Media Name & No & Online Media Name \\
\hline 1. & www.suara.com & 33. & www.makassar.terkini.id \\
\hline 2. & www.bisnis.com & 34. & www.riauterkini.com \\
\hline 3. & www.bola.com & 35. & www.tribun-medan.com \\
\hline 4. & www.detik.com & 36. & www.manadonews.co.id \\
\hline 5. & www.tribunnews.com & 37. & www.covesia.com \\
\hline 6. & www.gatra.com & 38. & www.kumparan.com \\
\hline 7. & www.jpnn.com & 39. & www.bernas.id \\
\hline 8. & www.jurnalsumatra.com & 40. & www.ayobandung.com \\
\hline 9. & www.liputan6.com & 41. & www.lintaslampung.com \\
\hline 10. & www.gosumut.com & 42. & www.detikawanua.com \\
\hline 11. & www.metrotvnews.com & 43. & www.pelitaekspres.com \\
\hline 12. & www.riaumandiri.co & 44. & www.obsessionnews.com \\
\hline 13. & www.berazam.com & 45. & www.batamnews.co.id \\
\hline 14. & www.tribunjateng.com & 46. & www.marwahkepri.com \\
\hline 15. & www.harianjogja.com & 47. & www.dream.co.id \\
\hline 16. & www.suaramerdeka.com & 48. & www.sulutdaily.com \\
\hline 17. & www.timesindonesia.co.id & 49. & www.riau24.com \\
\hline 18. & www.jambiindependent.co.id & 50. & www.uzone.id \\
\hline 19. & www.tribunjambi.com & 51. & www.kabarmakassar.com \\
\hline 20. & www.jamberita.com & 52. & www.minangsatu.com \\
\hline 21. & www.tempo.co & 53. & www.metrojambi.com \\
\hline 22. & www.jubi.co.id & 54. & www.netralnews.com \\
\hline 23. & www.viva.co.id & 55. & www.rilis.id \\
\hline 24. & www.mediakepri.co.id & 56. & www.batamtoday.com \\
\hline 25 . & www.wartakepri.co.id & 57. & www.cumicumi.com \\
\hline 26. & www.batamclick.com & 58. & www.bintang.com \\
\hline 27. & www.okezone.com & 59. & www.bunaken.co.id \\
\hline 28. & www.goriau.com & 60. & www.telegrafnews.co \\
\hline 29. & WWW.rmol.co & 61. & www.tirto.id \\
\hline 30. & www.arah.com & 62. & www.inforiau.com \\
\hline 31. & Www.indotimur.com & 63. & www.radarpekanbaru.com \\
\hline 32. & www.sulutnews.com & & \\
\hline
\end{tabular}

Note: The names of the media above are obtained from the official website of the press council: dewanpers.or.id

As described in the methods section, to ensure the reliability of the categorizations defined in this study, we had conducted a pilot study and calculated the reliability using Cohen's Kappa consistency test. The categorizations, namely grammatical errors, subjective errors, and eyewitness that have been declared reliable is used to examine the 
news in the 63 media aforementioned. From the Cohen's Kappa inter-coder reliability test, it can be concluded that all categorizations used in this study have a significant agreement between coder 1 and coder 2 with significant $0.000(<0.05)$. Cohen's Kappa coefficient value from the category 'gramatical errors' is 0.898 ; 'subjective errors' is 0.347 ; 'eyewitness' is 0.618 , and 'third hands' is 0.600 . Therefore, it can generally be concluded that all categories measured by coder 1 have an agreement with coder 2 .

\begin{tabular}{cccc}
\multicolumn{4}{c}{ Table 2. Inaccuracies in Each Media Category } \\
\hline No & Media Category & $\begin{array}{c}\text { Amount of } \\
\text { Media }\end{array}$ & $\begin{array}{c}\text { Amount of } \\
\text { Inaccuracies }\end{array}$ \\
\hline 1. & Economics, technology, and business & 3 & 53 \\
2. & Lifestyle and entertainment & 5 & 59 \\
3. & Regional & 23 & 228 \\
4. & Politics, law, and crime & 8 & 69 \\
5. & General & 23 & 156 \\
6. & Sports & 1 & 2 \\
& Total & 63 & 567 \\
\hline
\end{tabular}

Note: The amount of inaccuracies listed in this table comes from grammatical errors

Based on the Table 2, it can be concluded that media with 'genre' or specifically economics, technology, and business most often write inaccuracies. In three news stories, there are 53 grammatical errors written by the journalists. After that, lifestyle and entertainment media made the second most frequent error, where there are 59 errors in their 5 news stories.

Less Thorough in Journalistic Language

The results of this study indicate that online news media in Indonesia lacks attention to the language of journalism as a language that must be used in mass media reporting in Indonesia. There are a lot of grammatical errors, which is an indication that online media in Indonesia is less thorough. Every Indonesian online news media has 10 (rounding of 9.81) objective errors in average; with the highest to lowest error order: letter use (53.8 percent), words writing (28.2 percent), punctuation use (16.7 percent), and the use of numbers and numbers symbol (1.3 percent).

Table 3. Grammatical Errors

\begin{tabular}{cccc}
\hline No & Indicator & Number of & Percentage \\
& & Errors & \\
\hline 1. & Letter use & 319 & 53.8 \\
2. & Words writing & 167 & 28.2 \\
3. & Punctuation use & 99 & 16.7 \\
4. & The use of numbers and numbers symbol & 8 & 1.3 \\
& Total & 593 & 100 \\
\hline
\end{tabular}

Note: Errors in grammatical writing that occur in news in online media

In Table 3, we can see that there are 319 errors in writing letters. These mistakes dominate inaccuracies that occur in online media in Indonesia. The total error in writing these letters is five times more than the population itself. Every news has an average of 5 letter writing errors. One of the mistakes in writing letter can be seen in Figure 1. This figure shows a title that writes letter ' $\mathrm{d}$ ' in word 'Dengan' (with) in capital letters. This is inaccuracy in letter use, because the letter ' $d$ ' in 'dengan' word must be written in lowercase. 


\title{
Viral Medsos
}

\section{Sindir SBY Dengan Pukul Mangkok, Hotman Paris: Bapak SBY Nonton TV Ngak?}

Figure 1. Inaccurate in Letter use and word writing (source: medan.tribunnews.com/2018/09/08/sindir-sby-dengan-pukul-mangkok-hotman-parisbapak-sby-nonton-tv-ngak)

Typos or word writing errors are ranked second in objective errors. Although not as high as words writing, 167 errors remain high numbers, considering the number is twice more than the population of this study. It proves that online media is less accurate in checking the correctness of word writing. This error is not too much of a problem if the typo does not change the word it should. However, if the typo happens to have a meaning far from what should be written, the credibility of the online media in question can be questioned. One of the errors in writing letters can be seen in Figure 1. The figure shows a title that says 'Ngak' (no), where it should be written 'Nggak' (no). Another example can be seen in Figure 3, where the word 'aktivitas' (activity) is written as 'aktifitas.'

\author{
JAMBII-INDEPENDENT.CO.ID-Pemerintah secara resmi menetapkan kuota CPNS \\ 2018 sebanyak 238.015 orang. Penetapan ini dipertegas dalam Peraturan Menteri \\ Pendayagunaan Aparatur Negara dan Reformasi Birokrasi Republik Indonesia (PermenPAN. \\ RB) Nomor 36 Tahun 2018 Tentang Kriteria Penetapan Kebutuhan Pegawai Negeri Sipil dan \\ Pelaksanaan Seleksi Calon Pegawai Negeri Sipil Tahun 2018.
}

Permenpan RB Nomor 36 Tahun 2018 diterbitkan sebagai persiapan pelaksanaan seleksi

CPNS tahun 2018.

Figure 2. Punctuation use (source: jambiindependent1.rssing.com/chan-

56081239/all_p734.html)

There are 99 errors in writing punctuation marks. One of the mistakes can be seen in the Figure 2. In this news, the writing of the abbreviation 'PermenPAN-RB' (Regulation of the Minister of Administrative and Bureaucratic Reform of the Republic of Indonesia) was not consistent. In the first sentence, the punctuation dash is used, but in the subsequent sentence, the punctuation is not used. If we average the results, then each news has at least one error in writing punctuation. 


\begin{abstract}
Kata Helmi, aktifitas di pelabuhan tersebut memang cukup padat, karena sebagai
akses anak sekolah dan masyarakat. Sehingga untuk sementara masyarakat pengguna pelabuhan dialihkan ke Pelabuhan Pangkalan Balai yang memang jaraknya cukup jauh sekira 2 kilometer.

Helmi menjelaskan, atas kondisi itu Pelabuhan Kandis menjadi prioritas pembangunan ditahun 2019 mendatang. Yang rencananya akan dilakukan oleh Dinas Perhubungan Kabupaten Karimun dengan menggunakan anggaran yang bersumber dari Dana Alokasi Khusus (DAK).
\end{abstract}

Figure 3. Words writing and the use of number and symbol (source: batamclick.com)

In contrast, inaccuracy in writing number and symbol is very low, that is 1.3 percent. We can see the example in Figure 3. In journalistic language, numbers consisting of one digit should be written in letters. Meanwhile, news in the Figure 3 wrote ' 2 ' instead of ' $d u a$ ' (two). However, the finding of a low number of inaccuracy in writing numbers can also be regarded as something that is not special because the numbers are not as many as the letters in a news story. Therefore, the least error in writing numbers compared to letters can be said to be normal.

High in 'Imbalance' but Low in 'Inaccurate Title'

The standard deviation of grammatical errors and subjective errors is 7.96. This means that online media in Indonesia has a very high error range; there are online media that make no mistakes at all, but there are also those which make 36 errors in a story.

Table 4. Subjective Errors

\begin{tabular}{cccc}
\hline No & Indicator & Amount of Inaccuracies & Percentage \\
\hline 1. & Inaccurate title & 4 & 6.4 \\
2. & Imbalance & 51 & 80.9 \\
\hline
\end{tabular}

Note: Imbalanced news writing often occurs in online media. Meanwhile, news with inaccurate titles, such as click bait, are very few.

Furthermore, Indonesian online media has a low inaccurate title, which is 6.4 percent. The low percentage of inaccurate title writing shows that the majority of online media in Indonesia can maintain professionalism in writing news headlines. Their titles also represent the content of news or do not click bait.

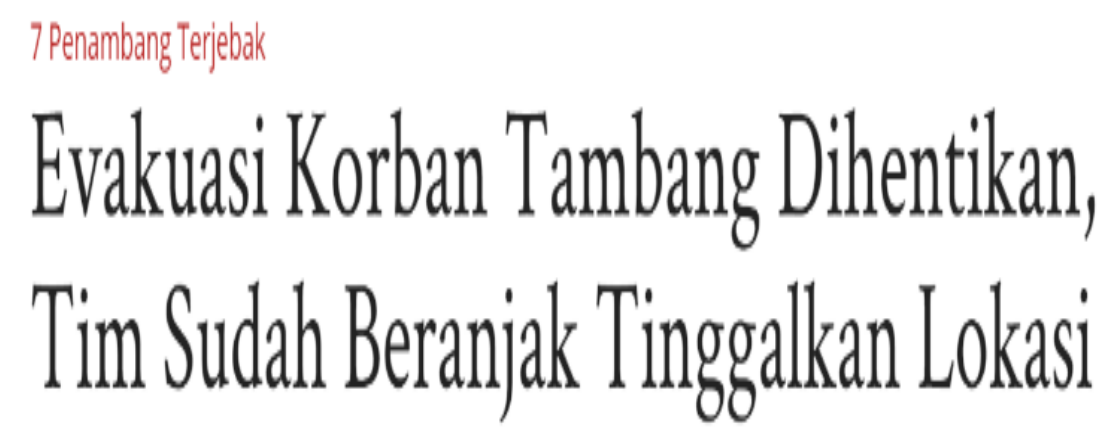

Figure 4. The title of imbalance news (source:

jambi.tribunnews.com/2018/09/05/evakuasi-korban-tambang-dihentikan-tim-sudahberanjak-tinggalkan-lokasi) 


\title{
Informasi yang dirangkum, siang ini, Rabu (5/9), seluruh tim yang turun langsung ke lapangan bertolak ke Kota Bangko.
}

\author{
"Tadi pagi sebagian petugas sudah keluar di lokasi dan stand by \\ di Polsek Sungai Manau dan sore ini akan ke Bangko," kata \\ petugas yang ikut dalam tim evakuasi. (*)
}

Figure 5. Quotation in imbalance news (source:

jambi.tribunnews.com/2018/09/05/evakuasi-korban-tambang-dihentikan-tim-sudahberanjak-tinggalkan-lokasi)

Indonesian online media is very weak in applying balanced reporting. By balanced means that all parties have equal opportunities. Most of Indonesian online media (79.3 percent) reported imbalance stories. The news they have reported only highlights one party, while the other party which should be related is not too highlighted or even ignored. An example is in the news in Figure 4 and 5. The title of the news is "Evakuasi Korban Tambang Dihentikan, Tim Sudah Beranjak Tinggalkan Lokasi” (The Evacuation of Mine Victims has been Stopped, the Team has Left the Location), but the quotation only came from officers and there was no quote from victims at all.

Table 3. Sources

\begin{tabular}{cccc}
\hline No. & Indicator & Number of Errors & Percentage \\
\hline 1. & Eyewitness & 50 & 79.3 \\
2. & Third hand & 11 & 17.5 \\
3. & Don't know & 2 & 3.2 \\
& Total & 63 & 100 \\
\hline
\end{tabular}

Note: Various ways that journalists do in getting news sources

Online media in Indonesia tend to get their source directly or through eyewitness (79.3 percent). This is good because as explained by (Berry, 1967), information obtained through eyewitness is more reliable than that obtained through third hand. In addition, there are few news stories (17.5 percent) that use sources originating from a third-hand. We can see news with third hand source in figure 6. At the bottom of the news, kompas.com was written as all news sources.

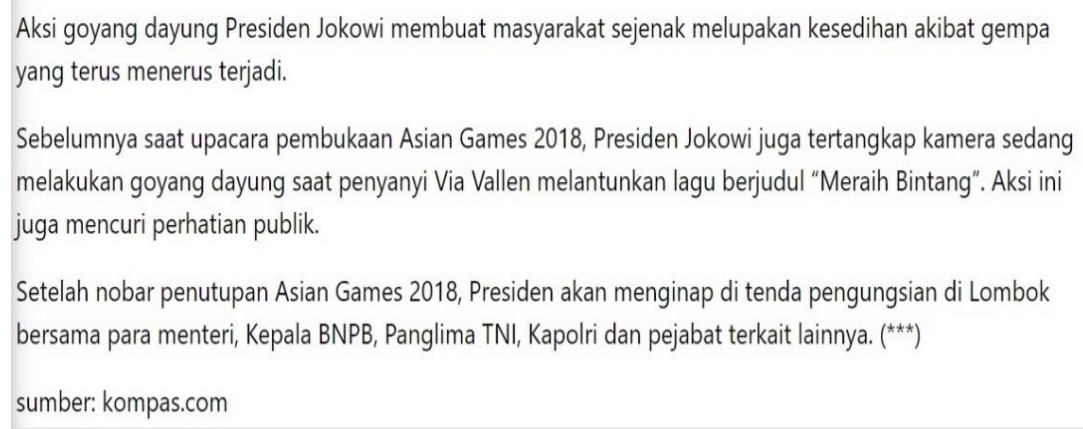

Figure 6. News that has sources from the third hand (source:

mediakepri.co.id/2018/09/goyang-dayung-presiden-jokowi-saat-penutupan-asiangames-di-lombok-hibur-para-pengungsi/)

It has to be remembered that the sample of this study is news from online media that have been administratively and factually verified by 'Dewan Pers.' This does not 
include online media which have not been verified yet. Therefore, there will be more possibilities for the inaccuracy of online press companies as a whole.

\section{Discussion}

The results of this study indicate that the demand for speed in releasing news online has an impact on the low accuracy of journalistic language and journalistic techniques. Online news media in Indonesia have high inaccuracies in grammar, especially media with economics, technology, and business 'genre.' This shows that online journalistic media in Indonesia are not thorough in writing their stories. This can be considered simple if it does not change the meaning, but still it violates professional norms (Shapiro et al., 2013). However, this finding does not conform to the compromise norm, because there are many inaccuracies in simple matters such as writing letters and words.

In media ethics theory, accuracy (along with verification) is the first issue mentioned in the journalism ethical problems (Ward, 2008). As the first area of media ethics problem, the accuracy is significant in every story or news report in any mass media industry, including mass media industry in online journalism too. Speed that has been the main advantage of online journalism cannot be the excuse for online media for making an inaccurate story.

This finding clearly does not fulfill 'bahasa jurnalistik' (journalistic language) that every news written by the Indonesian mass media must use standard Indonesian language, good and right and at least make EYD a benchmark in writing news in the mass media (Chaer, 2010). The high inaccuracy of news writing in Indonesian online media proves that online media in Indonesia must have a good checking system, namely by applying a news script review system to be printed in layers. The first layer is the editor that plays the function of the gatekeeper and the second layer is a copy of the editor specifically to check the language structure only. Thus, a copy editor must have a good linguistic background, for example an Indonesian language scholar.

Our findings prove that correction is important. As stated in Brautović, Maštrapa, \& John, the media need to have error management in order to be accountable to their audience. This was done to maintain or increase its credibility. Error management needs to be enforced to prevent their own staff from neglecting fact-checking. Double-checking before publishing news in online media is very necessary. If something goes wrong, the journalist's name and errata need to be written on the same news page to contribute to reducing the error rate, as was done by the online media CNN Indonesia in 2015. By doing so, future mistakes can be prevented. Errors that have already existed can also be corrected (Brautović et al., 2020).

News media companies need to apply certain methods to their journalists before spreading the news, that is, by focusing not only on the results but also on how journalists arrive at their findings. Therefore, reporters will provide good service to readers. Readers' trust in news accounts will become higher too (Maguire, 2016).

The second finding in this study is a high range of inaccuracies; that is, there are stories that have no inaccuracy at all but some are nearly 40. This finding indicates a wrong procedure in the media with high inaccuracy. This is not a problem of inaccuracy, but it is a problem of lever weakness (Duffy \& Tan Rui Si, 2018) and the gatekeeping process (Putri, 2012) as a whole in a medium. The high number of inaccuracies indicates that the error occurs not because of accident, but because you do not know what is right.

This indicates an imbalance in the role of the gatekeeper in media that has zero errors and many errors. Supposedly, the gatekeeper is the main gateway in saving news 
from mistakes, whether it is an objective error. Gatekeepers must ensure leverage as their strategy so that news can be ascertained accurate (Shapiro et al., 2013).

Accuracy itself can be interpreted in various ways. In Shapiro, Brin, Bédard-Brûlé, $\&$ Mychajlowycz, accuracy can be interpreted as 'pure' accuracy (literal truth) and 'what is told' accuracy (uncritical reliance on the associated source). There is also greater accuracy (related to overall thrust in a context in the news) and interpretation accuracy (Shapiro et al., 2013). Each of these accuracy needs to be realized through various verifications, according to the accuracy characteristic.

The enthusiasm to carry out verification with high standards as much as possible does not only burden the gatekeepers, but also becomes the enthusiasm of the media crew as well as becomes a media habit or routine. Gatewatching--evaluating by the audience-which is a sign of the opening of a media can also be one of the latest options in implementing news checking (Bruns, 2011). Online media verifications must be done deftly and become a habit. Because, it is undeniable that the pressure to make a story update in a very short time interval cannot be avoided (Diekerhof \& Bakker, 2012). Another finding of this study is the high level of imbalance in news reporting. Compared to the inaccuracy of writing letters and words, this error is more serious and can be fatal. It is said to be fatal because balance is the 'life' of journalism.

Journalist has to cover all sides instead of cover both sides, since there might be more than two parties in a news (Laksono, 2010). On the contrary, most of Indonesian online media (79.3 percent) reported imbalanced stories. The news they have reported only highlights one party, while the other party which should be related is not too highlighted or even ignored.

The facts aforementioned contradict the ethics of mass media in Indonesia. The Indonesian Journalistic Code of Ethics issued by the Indonesian Journalists Association (PWI) emphasizes the importance of balance several times. In the Journalistic Code of Ethics Chapter II Article 5 and stated that Indonesian journalists present the news in a balanced and fair manner, prioritizing the accuracy of speed and mixing facts and opinions themselves. While Article 7 emphasizes balanced news presentation.

Delivering imbalanced news is a danger for any type of mass media, because that means they have lost the essence of journalism itself. Journalists must be able to maintain the independence of the people they cover, in other words, journalists should not take sides and lean towards certain parties (Kovach, Bill; Rosenstiel, 2001). However, we cannot be 100 percent objective in pouring facts into writing, therefore the reportage carried out by journalists is actually a 'subjective objectivity' (Ishwara, 2011).

Anyway, the high imbalanced news usually occur without complete news elements. The complete news element is $5 \mathrm{~W}+1 \mathrm{H}$, which includes: events that contain the facts of what happened, who (who or people who were and are involved in the reports), why (why does it happen or background that makes the event), where (identification of the occurrence event location), when (the time it happens), and how (the process of an event) (Chaer, 2010). Meanwhile, online media seems to be more subject to speed or deadline compared to the completeness of the news (Diekerhof \& Bakker, 2012). Therefore, it is safe to say that online media can do non-balanced reporting not because they deliberately side with certain sources, but because they do not exist--or do not take the time to explore other sources more deeply.

Journalism products, regardless of medium, should have a high standard of accuracy. Online media can have the same high accuracy as print media, because online media is called a derivative of print media (Doudaki \& Spyridou, 2013). Online media 
can sustain the search for news sources through eyewitness--such as finding from this research--and then maintaining engagement (Mersey et al., 2010) as a form of media richness (Sheer, 2011).

As part of the news media in total, press companies have freedom of expression, but they also have to be ethical (Pers, 2011). Providing a special place for citizen journalism (Rogers, 2014) can be done as a form of openness towards gates, but the real gatekeeper function of the media must still be carried out properly. Affective news writing (Papacharissi, 2015) and emotional involvement in reporting news (Rosas, 2018) can be done, as long as credibility (Choi \& Kim, 2017) and excellency (Shapiro et al., 2006) can be maintained.

Limitation in this study is that we did not measure traditional media such as print, television and radio; so that the results in this study cannot be compared with the mass media. This is also a suggestion for future research in order to measure inaccuracies in other media and then compare the results of the research with those in this study. Future research may also consider new models or measurements (Lance Holbert \& Grill, 2015). Another thing that can be a suggestion for future research is to update studies on the inaccuracy of online journalistic media, because research like this is better done regularly (Berry, 1967).

\section{Conclusion}

The high demand for speed on news in online media makes inaccuracies inevitable. Online journalism media in Indonesia--especially those with specialization in economics, technology, and business--have high inaccuracies in writing letters and words compared to other categories of inaccuracy. Not only high in grammatical errors, online media in Indonesia is also high in presenting imbalanced news. This fact indicates that a more effective journalistic media verification mechanism is needed for online journalism. Verification must be mandatory for journalists and gatekeepers to minimize inaccuracies. Online news media must uphold ethics like other news media such as newspapers and television. The implementation of methods and routines that maintain accuracy needs to be enforced so that the credibility of online news media is established. Furthermore, future research can compare the inaccuracies between online media and print media where both produce written news.

\section{Conflict of Interest}

We certify that there is no conflict of interest with any financial, personal, or other relationships with other people or organization related to the material discussed in the manuscript.

\section{Acknowledgements}

This research was conducted to fulfill one of the requirements for graduation of Fikry Zahria Emeraldien's doctoral study at the Faculty of Social and Political Sciences in Universitas Airlangga, Indonesia.

\section{References}

Adhiarso, D. S., Utari, P., \& Hastjarjo, S. (2018). The Influence of News Construction and Netizen Response to the Hoax News in Online Media. Jurnal The Messenger, 10(2), 162. https://doi.org/10.26623/themessenger.v10i2.782

Akoje, T. P., \& Rahim, M. H. A. (2014). Development of journalism ethics: A 
comparative analysis of codes of ethics in Nigeria, United kingdom, United States of America, India and Russia. Jurnal Komunikasi: Malaysian Journal of Communication, 30(2), 221-238. https://doi.org/10.17576/jkmjc-2014-3002-12

Alzamora, G., \& Tárcia, L. P. T. (2012). Convergence and Transmedia : Brazilian Journalism Research, 8(1), 22-34. http://bjr.sbpjor.org.br/bjr/article/view/407

Berry, F. C. (1967). A Study of Accuracy in Local News Stories of Three Dailies. Journalism Quarterly, 44(3), 482-490. https://doi.org/10.1177/107769906704400309

Brautović, M., Maštrapa, S. B., \& John, R. (2020). Accuracy in online media: Insufficient journalistic routines in fact-checking and corrections. Medijske Studije, 11(21), 6686. https://doi.org/10.20901/ms.11.21.4

Bruns, A. (2011). Gatekeeping, Gatewatching, Real-Time Feedback: Brazilian Journalism Research, 7(11), 117-136.

Chaer, A. (2010). Bahasa Jurnalistik. Rineka Cipta.

Chari, T. (2013). New Communication Technologies and Journalism Ethics in Zimbabwe: Practices and Malpractices. Communication and Media Technologies, 3(2), 112-136. https://doi.org/10.5176/2301-3729_jmcomm12.42

Choi, S., \& Kim, J. (2017). Online news flow: Temporal/spatial exploitation and credibility. Journalism, 18(9), 1184-1205. https://doi.org/10.1177/1464884916648096

Coddington, M. (2015). Clarifying Journalism's Quantitative Turn: A typology for evaluating data journalism, computational journalism, and computer-assisted reporting. Digital Journalism, 3(3), 331-348. https://doi.org/10.1080/21670811.2014.976400

Cunningham, S., \& Craig, D. (2016). Online entertainment: A new wave of media globalization? International Journal of Communication, 10, 5409-5425.

Diekerhof, E., \& Bakker, P. (2012). To check or not to check: An exploratory study on source checking by Dutch journalists. Journal of Applied Journalism \& Media Studies, 1(2), 241-253. https://doi.org/10.1386/ajms.1.2.241_1

Doudaki, V., \& Spyridou, L. P. (2013). Print and Online News: Remediation practices in content and form. Journalism Studies, 14(6), 907-925. https://doi.org/10.1080/1461670X.2012.746860

Duffy, A., \& Tan Rui Si, J. (2018). Naming the Dog on the Internet: Student reporters' verification tactics for non-elite newsmakers online. Digital Journalism, 6(7), 910927. https://doi.org/10.1080/21670811.2017.1377092

Fahmy, S., \& Johnson, T. J. (2007). Mediating the Anthrax Attacks: Media Accuracy and Agenda Setting During a Time of Moral Panic. Atlantic Journal of Communication, 15(1), 19-40. https://doi.org/10.1080/15456870701212583

Fauzi, G. (2015). Megawati: Bubarkan KPK Jika Tak Ada Korupsi. CNN Indonesia. https://www.cnnindonesia.com/nasional/20150818123757-12-72853/megawatibubarkan-kpk-jika-tak-ada-korupsi

Ishwara, L. (2011). Jurnalisme dasar. 188.

Jacobson, S. (2010). Emerging models of multimedia journalism: A content analysis of multimedia packages published on nytimes.com. Atlantic Journal of Communication, 18(2), 63-78. https://doi.org/10.1080/15456870903554882

Joye, S. (2010). News media and the (de)construction of risk: How Flemish newspapers select and cover international disasters. Catalan Journal of Communication \& Cultural Studies, 2(2), 253-266. https://doi.org/10.1386/cjcs.2.2.253_1 
Karyotakis, M. A., Antonopoulos, N., \& Saridou, T. (2019). A case study in news articles, users comments and a facebook group for article 3 of the Greek constitution. Kome, 7(2), 37-56. https://doi.org/10.17646/KOME.75672.31

Kovach, Bill; Rosenstiel, T. (2001). NRJ Books: The Elements of Journalism: What Newspeople Should Know and the Public Should Expect. Newspaper Research Journal. https://doi.org/10.1177/073953290102200409

Laksono, D. D. (2010). Jurnalisme Investigasi.

Lance Holbert, R., \& Grill, C. (2015). Clarifying and expanding the use of confirmatory factor analysis in journalism and mass communication research. Journalism and Mass Communication Quarterly, 92(2), 292-319. https://doi.org/10.1177/1077699015583718

Ma, T., Ramli, R., \& Abdul Rahman, N. A. (2018). Challenges of Dissemination of Islamrelated Information for Chinese Muslims in China. Jurnal The Messenger, 10(1), 1. https://doi.org/10.26623/themessenger.v10i1.767

Maguire, M. (2016). Methodology matters: A framework for gauging accuracy and impact. Journal of Applied Journalism \& Media Studies, 5(3), 405-422. https://doi.org/10.1386/ajms.5.3.405_1

Maier, S. R. (2005). Accuracy matters: A cross-market assessment of newspaper error and credibility. Journalism and Mass Communication Quarterly, 82(3), 533-551. https://doi.org/10.1177/107769900508200304

Marshall, H. (1972). Newspaper Accuracy in Tucson. Journalism Quarterly, 54(1), 165169. https://doi.org/10.1177/107769907705400127

Mersey, R. D., Malthouse, E. C., \& Calder, B. J. (2010). Engagement with online media. Journal of Media Business Studies, 7(2), 39-56. https://doi.org/10.1080/16522354.2010.11073506

Michael W. Singlatery; Richard Lipsky. (1977). Accuracy in Local TV News. Journalism Quarterly, 54(2), 362-364.

Papacharissi, Z. (2015). Toward New Journalism(s): Affective news, hybridity, and liminal spaces. Journalism Studies, 16(1), 27-40. https://doi.org/10.1080/1461670X.2014.890328

Pers, J. D. (2011). Era Media Online, New Media Antara Kemerdekaan Berekspresi dan Etika. Jurnal Dewan Pers, 4, 1-75.

Pesquisa, B. De. (2017). Routines in Web Journalism : Brazilian Journalism Research, 13(1), 20-37.

Potter, W. J., \& Thai, C. L. (2019). Reviewing media literacy intervention studies for validity. Review of Communication Research, 7(2019), 1-29. https://doi.org/10.12840/ISSN.2255-4165.018

Putri, N. P. W. (2012). Gateekeeping Process dalam Citizen Journalism Berkaitan dengan Partisipasi Masyarakat dalam Menyampaikan Informasi Lalulintas di Radio Idola FM Semarang. Jurnal The Messenger, 4(1), 35-42.

Rizkiansyah, M., Muslikhin, \& Wiratma, M. (2020). Between clarity and novelty implementation in Indonesia online media according to the principle of journalist. Jurnal Komunikasi: Malaysian Journal of Communication, 36(3), 1-13. https://doi.org/10.17576/JKMJC-2020-3603-01

Rogers, S. (2014). Data journalism is the new punk. British Journalism Review, 25(2), 31-34. https://doi.org/10.1177/0956474814538181

Rosas, O. V. (2018). News Media and the Emotional Public Sphere| Strategic Avoidance and Strategic Use: A Look into Spanish Online Journalists' Attitudes Toward 
Emotions in Reporting. International Journal of Communication, 12(0), 19.

Shapiro, I., Albanese, P., \& Doyle, L. (2006). What Makes Journalism "Excellent"? Criteria Identified by Judges in Two Leading Awards Programs. Canadian Journal of Communication, 31(2), 425-445. https://doi.org/10.22230/cjc.2006v31n2a1743

Shapiro, I., Brin, C., Bédard-Brûlé, I., \& Mychajlowycz, K. (2013). Verification as a strategic ritual how journalists retrospectively describe processes for ensuring accuracy. Journalism Practice, 7(6), 657-673. https://doi.org/10.1080/17512786.2013.765638

Sheer, V. C. (2011). Teenagers' use of MSN features, discussion topics, and online friendship development: The impact of media richness and communication control. Communication Quarterly, $59(1)$ 82-103. https://doi.org/10.1080/01463373.2010.525702

Supadiyanto, S. (2020). (Opportunities) Death of Newspaper Industry in Digital Age and Covid-19 Pandemic. Jurnal The Messenger, 12(2), 192. https://doi.org/10.26623/themessenger.v12i2.2244

Tandoc, E. C., \& Foo, C. Y. W. (2018). Here's What BuzzFeed Journalists Think of Their Journalism. Digital Journalism, 6(1), 41-57. https://doi.org/10.1080/21670811.2017.1332956

Ward, S. J. A. (2008). Journalism ethics. The Handbook of Journalism Studies, 307-323. https://doi.org/10.4324/9781315167497-20 